\title{
The Contribution of Indonesian Language Learning towards Students' Character Education
}

\author{
Zulkifli \\ Universitas Lambung Mangkurat \\ Banjarmasin, Indonesia \\ zulkiflimusaba59@gmail.com
}

\begin{abstract}
The contribution of Indonesian language learning towards students' character education will be actualized if its establishment is going through effective ways. Indonesian language learning should be concerning on several significant points: the selection of appropriate materials, and the application of methods and techniques of learning that allows students to feel the benefits of the learning process they are going through. Indonesian language learning should provide a range of inputs on aspects of character education, so that students do not just learn Indonesian language, have the linguistic competence, and have good language skills, but students are also spiritedly raised to implement the good characters in their daily life, whether when they are at school, family, or social environment.
\end{abstract}

Keywords-contribution; Indonesian language; learning; character education

\section{INTRODUCTION}

Each learning process should be carried out effectively, so expectantly the determined goals will be achieved. One thing to keep in mind is the success and failure of language learning are situated in numerous factors, such as teaching methods, teaching materials, students' motivation and teaching quality [1]. Likewise, in Indonesian language learning, through the learning process students are expected to acquire adequate knowledge of the language (including literature), have language skills that are able to meet their daily needs, whether for students' needs of language learning, or their daily language usage. Besides, they are also expected to possess a positive attitude towards the Indonesian language. And finally, it is hoped that Indonesian language learning outcomes can be capable to contribute to the student's character education. In other words, learning the Indonesian language is not just for being competent at language skills, or having students' positive attitudes, but also to contribute to the building process of students' personality, or in specifics: to be a part of character education process for students. This assumption is in line with what [2] asserts, he declares that it can be argued that the learning process is a process of behavioral changes. Therefore, the language learning process is also an attempt to change the behavior of the students. Such amendment relates to the ability of students to put their learning experience to improve the language skills and the ability to adapt to the social environment that involves language as a communication tool. If students ever used to utilize a language that did not consider the need for harmonious interaction among others, then after they were involved in the process of learning a language, it would contribute to creating the atmosphere of the association better, the association that upholds the social value through the language they use.

\section{AN EFFECTIVE INDONESIAN LANGUAGE LEARNING}

Indonesian language learning process must take place effectively, and achieve the desired results in line with the predetermined target. One thing to keep in mind too is that success and failure of language learning lie in many factors, for example teaching methods, teaching materials, student's motivation and teachers' quality [1]. In terms of learning resources, teachers must be able to take full advantage. Ref. [3] states that learning resources in question can be compulsory and supplementary books, printed media (such as scientific journal articles and linguistic magazines), electronic media, environment, scholars, personal experiences, learners' interest and works.

Therefore, the learning success cannot be propped to one component only. An effective Indonesian language learning at least can be realized through a proper method (including techniques), teaching materials, or materials that fit the skills and needs of the students, students' high motivation in the learning process, and lastly the availability of high-qualified teachers. Subsequently, all of the learning processes should put the curriculum as a guiding reference for all activities. The standpoint of a curriculum is vastly imperative to direct the learning process to the right path.

Needless to say, a learning process is in accordance with the implemented curriculum. On the other hand, Indonesian language learning should also contribute to various things, including how to establish and strengthen students' character. Through all of this, the contribution of Indonesian language learning process toward character education for students will be revealed. Hence, the Indonesian language learning process ought to be in force. In the context of Indonesian language learning, literature learning is supposed to be incorporated. By learning literature as part of learning the Indonesian language, students are expected to be capable of obtaining a range of values from the inherent literary works. Ref. [4] agrees that literature education is comprehensive, 
far-reaching, and integrated since literature speaks about human and the intricacy of human life.

Indonesian language learning should be comprehensive, and contextual. More than that, expectantly it will provide tangible benefits for students. The learning process should not only emphasize the aspects of knowledge, but also provide opportunities for achieving aspects of language skills, and embed a positive attitude to the Indonesian language. This does not mean that linguistic and literary matters are unimportant, but the intended learning process must stick to the principle of benefits in a broader sense.

\section{THE CONTRIBUTION OF INDONESIAN LANGUAGE LEARNING TO STUDENTS' CHARACTER EDUCATION}

The main purpose of learning the Indonesian language is so that students are able to use the Indonesian language properly and correctly. Ref. [5] argue that the correct use of the Indonesian language means that it is in accordance with Indonesian language rules, while the use of good Indonesian language means that its use has the right taste value and is in accordance with the users' situation. Students are looked forward to being able to communicate with others by using the Indonesian language, either in oral form or in written form, and of course, it is ought to be in accordance with the allied situation. This also relates to how students acquire the skills to understand messages received/delivered based on the context [6]. If the students are about to express their intention verbally, then the form of language used must inherently describe the politeness and the values, so it will then relate to the application of character education. In other words, the learning process of Indonesian language can also contribute to the strengthening, as well as the cultivation of students' character education.

Indeed, it cannot be denied that not all elements of character education can be incorporated or internalized through the learning of Indonesian language and literature. Because it is also associated with an assortment of character education components. There are 18 elements in the curriculum, namely: religiosity, honesty, tolerance, discipline, hard work, creativity, independence, and democratic, curiosity, having nationalist enthusiasm, loving the nation, appreciating achievements, being friendly and communicative, loving peace, having reading excitement, taking care of environment, social attention, and responsibility [7]. What contribution can Indonesian language learning give to character education of the students? How is its application in the learning process?

\section{INDONESIAN LANGUAGE MATERIALS FOR STUDENTS CHARACTER EDUCATION}

The contribution of Indonesian language learning to character education of students can be pursued through learning or presentation of the material as follows:

\section{A. Instituting Positive Attitude towards the Indonesian Language}

The establishment of a positive attitude towards the Indonesian language needs to be conducted. Students supposed to be aware that the Indonesian language is an important part of national culture, since Indonesian language roles as the language of the country, the language of unity, and the language of tribeto-tribe converse. This positive attitude towards the Indonesian language shares love to the nation and foster the spirit of nationality among students. When students possess a positive attitude towards Indonesian language, it will encourage them to appreciate their national language in way more respectable, along with their correct and proper use of Indonesian language. The love of the students towards the Indonesian language must be firmly entrenched inside them, so as to love has become part of their character. Because, the so-called character must be up to the level of internalization in the real life [8]. This is manifested by the love of the students towards the Indonesian language, and the high level of awareness of it, so that the students could really uphold the language of unity, Indonesian, as the third point of the Youth Pledge.

\section{B. Learning Language Skills}

One of the main objectives of Indonesian language learning is that students are skilled in using the Indonesian language, both speaking and writing. In addition, students are also expected to be skilled at listening and reading. These four language skills are exceedingly prominent for students. Learning four language skills is diametrically related to character education. Listening and reading are in accordance with the elements of character education, they reflect a sense of curiosity and an excitement of reading. Then, through the activities of speaking and writing, the elements friendliness, creativity, and hard work can be revealed as a part of character education process. Moreover, in other certain situations, those four language skills could also be functioned in other elements of character education.

\section{Learning to Appreciate Literature}

Learning to appreciate literature means students are encouraged to appreciate literary works as part of the culture. Students should also value the authors. Appreciating the work of others is taken account of part of character education. Accordingly, by making use of literary works, students are expected to be more sensitive to people's lives. The founding of literary works cannot be separated from the dynamics of life in society. If students are trained to analyze literary works and/or make literary works, it will make them more creative. Creative students mean that they apply part of character education. On the other hand, students who like to read literature, then instinctively they also apply the character education: having a great excitement to read.

\section{Learning Language Error Analysis}

Students should be given experience in analyzing language use, for by analyzing language use, students are going to gain real 
experience. The students find the language errors that exist in the writing and speech, so it is expected to increase their attentiveness that language exists with rules. Indirectly, the students will be more appreciative of Indonesian language. Equally, it is associated with instituting positive attitude towards the Indonesian language.

\section{THE IMPLEMENTATION OF INDONESIAN LANGUAGE LEARNING AS A BRANCH OF EDUCATION FOR STUDENTS}

The way Indonesian language learning (and literary) contributes to character education of students (based on materials given to students) can be put forward as follows:

- In order to embed a sense of love of the nation and the spirit of nationalism, the teacher should use the Indonesian language as the language of instruction while teaching, and the students are ought to try to use the Indonesian language when interacting with the teacher. Except in some cases, teachers and students can use local languages, for example, to clarify a particular concept or material.

- Character education can be executed through learning language skills. Learning listening skills are done by familiarizing the students to listen to the conversations of others, including what they hear from the teacher and their friends. Through listening learning, students are educated to appreciate others who are speaking. The teacher evaluates the students, the extent to which his students absorb what he or she is listening to. Teachers can also ask students why students are unable to answer questions regarding what they hear. Then, through speaking learning, students are taught to apply language politeness. Students are taught not to use harsh words. Students are also taught to not interrupt other people's conversations, they are encouraged to be able to control themselves to give the speaker an opportunity to finish the conversation. Students are acclimatized to utilize honorific utterances, such as saying "congratulations" for particular moments like school graduation, friends' achievement in a championship, birthday greetings, and so on and so forth. The students are also habituated to greet each other. Through reading learning, teachers can assign tasks to students to search and read books and other materials to read, then the students are asked to make a summary of the book or other materials. This activity directly imparts a sense of curiosity and to enhance students' reading interest as a part of character education. Furthermore, through writing learning, students are mentored and encouraged to write. Learning writing is expected to encourage students to write and to be creative. Above and beyond, through writing activities, students are also trained to be honest, not to take the opinions of others (quoting from others' writings) without mentioning the source or what so-called plagiarism.
- Through learning how to appreciate literary works, the students will become used to appreciate the work of others. Firstly, the teacher provides literary works for students to read, then asks students to enjoy and review the literary works. Besides, the teacher can also ask students to create their own literary works, albeit in a simple form. This activity, which is a part of the application of character education, can give confidences to students to be creative.

- Through learning language error analysis, students are expected to be responsive to the importance of discipline in obeying the rules in using the language. Later, the teachers may ask their students to look for written materials, such as articles or other articles to read and analyze in order to see the presence and occurrence of an error in particular language use.

\section{CONCLUSION}

Indonesian language learning is not just a gift of knowledge about the Indonesian language with all its subjects, but it should also be viewed as a systematic effort for students to be skilled in Indonesian language (listening, speaking, reading and writing) and able to appreciate literary works as a part of Indonesian language learning. The students are expected to have a positive attitude towards the Indonesian language, which comprises having awareness of the magnitude of Indonesian language so as to foster them to use the Indonesian language properly and correctly as a part of their attachment of national culture. Creativity, discipline, loving the nation, and other components in character education can be actualized through learning the Indonesian language. However, all the efforts suggested requiring the creativity and high-awareness of the teacher to make the Indonesian language learning flourishing

\section{REFERENCES}

[1] Wahab, Abdul. 1991. Isu Linguistik: Pengajaran Bahasa dan Sastra. Surabaya: Airlangga University Press.

[2] Brown, $\mathrm{H}$ Douglas. Prinsip Pembelajaran dan Pengajaran Bahasa. Terjemahan Noor Cholis dan Yusi Avianto Pareanom. Jakarta: Pearson Education, Inc.

[3] Pringgawidagda, Suwarno. 2002. Strategi Penguasaan Berbahasa. Yogyakarta: Adicita Karya Nusa.

[4] Amir, Hazim. 1990. Pendidikan Sastra Lanjut. Malang: IKIP Malang.

[5] Arifin, E Zaenal dan S Amran Tasai. 2009. Cermat Berbahasa Indonesia untuk Perguruan Tinggi. Jakarta: Akademika Pressindo.

[6] Seelye, H Ned. 1994. Teaching Culture. USA: National Textbook Company.

[7] Ridhahani. 2013. Transformasi Nilai-Nilai Karakter/Akhlak dalam Proses Pembelajaran. Yogyakarta: LKiS.

[8] Hadi, Rizali. 2013. Pembelajaran Nilai Kejujuran Berbisnis (Suatu Pengalaman Empiris). Yogyakarta: Aswaja Pressindo. 